УДК 631.148:338.439.5, DOI 10.31210/visnyk2018.02.08

(C) 2018

Ткаченко А. С., кандидат технічних наук

ВНЗ Укоопспілки «Полтавський університет економіки і торгівлі»

\title{
СТАН ТА ПЕРСПЕКТИВИ ОРГАНІЧНОГО СІЛЬСЬКОГО ГОСПОДАРСТВА У РЕГІОНАХ УКРАЇНИ
}

\section{Рецензент - доктор технічних наук С. В. Гаркуша}

У статті наведено дані щзодо стану органічного виробництва в областях України. Проаналізовано кількість операторів органічного ринку, загальні площі земель, щзо мають статус органічних, та земель, шзо знаходяться у перехідному періоді. Визначено області з найкрашими тенденціями розвитку органічного землеробства, а також проаналізовано взаємозалежність між станом органічного землеробства та кількістю органічних операторів. Надано рекомендації щзодо покращуання ситуащії у галузі органічного землеробства та окреслені перспективи подальших досліджень.

Ключові слова: органічне виробництво, органічне землеробство, перехідний період, оператор органічного ринку, сільське господарство.

Постановка проблеми. Екологічно чисте харчування $\epsilon$ запорукою міцного здоров'я. У наш час більшість продуктів, що реалізуються у торгових мережах, мають у своєму складі хімічні харчові добавки, i, не дивлячись на те, що вони містяться у продуктах у мінімальних концентраціях, вживання таких продуктів є вкрай небажаним.

Тренд здорового харчування розповсюджується досить швидко. Люди все більше дбають про своє здоров'я. Однак існують невирішені проблеми, оскільки органічні продукти купити пересічному українцю вкрай важко. Вони продаються лише у спеціалізованих магазинах, які здебільшого працюють у великих містах. Звісно, що, наприклад, у сільській місцевості продавати органічні продукти $€$ невигідно і недоцільно, оскільки сільське населення має власні угіддя $\mathrm{i}$ вирощує продукцію для власного споживання. За таких умов продукція найчастіше $\epsilon$ органічною, але додаткового підтвердження у вигляді сертифікатів дрібним агровиробникам не потрібно. Найбільш вигідним продаж органічних продуктів $\epsilon$ в урбанізованих міста, зокрема 3 великим населенням. До того ж, значення має і середній дохід населення, адже органічна продукція $\epsilon$ на рівень дорожчою за неорганічну. Невеликі обласні центри, такі як Полтава, Чернівці, Житомир тощо, лишаються поза увагою дистриб'юторів органічної продукції. У таких міс- тах зазвичай працює 1-2 магазини, що реалізують органічну продукцію, і контингент споживачів є вкрай обмеженим. Однак істотний вплив на реалізацію органічної продукції має також стан органічного виробництва в регіоні.

Зрозуміло, що органічне виробництво потребує значних вкладень. У цьому випадку на допомогу може прийти держава - доцільним є розширення програм підтримки виробників органічної продукції. Такі програми вже існують, проте вони мають бути більш потужними та відкритими, так як це функціонує в Європі.

Аналіз стану органічного сільського господарства у регіонах України дасть змогу з'ясувати існуючі проблеми у галузі органічного землеробства, виявити загальні тенденції та надати рекомендації щодо покращання стану органічного виробництва.

Аналіз останніх досліджень і публікацій 3 даної проблеми. У країнах ЄС та у світі в цілому стрімко поширюється органічне виробництво - цілісна система господарювання та виробництва харчових та інших продуктів, яка поєднує в собі найкращі практики, що враховують збереження довкілля, рівень біологічного розмаїття, збереження природних ресурсів, застосування високих стандартів належного утримання тварин та методів виробництва, які відповідають певним вимогам до продуктів, виготовлених із використанням речовин і процесів природного походження [6].

Початок органічному виробництву було покладено у першій половині XX сторіччя, а саме у 1924 p. лекціями Рудольфа Штайнера. Шляхом встановлення принципів для контролюючої системи органічного сільського господарства виробники та споживачі відгукнулись на негативні аспекти традиційного індустріалізованого інтенсивного сільського господарства. Це розпочалося, коли синтетичні добрива та пестициди почали широко використовувати (у 1920-х та 1930-х роках) та отримали поштовх для розвитку в 1960-х роках, коли сільське господарство почало ставати більш спеціалізованим та інтенсифікованим [5].

Згідно 3 українським законодавством, вироб- 
ництво органічної продукції (сировини) - виробнича діяльність фізичних або юридичних осіб (у тому числі з вирощування та переробки), де під час такого виробництва виключається застосування хімічних добрив, пестицидів, генетично модифікованих організмів (ГМО), консервантів тощо, та на всіх етапах виробництва (вирощування, переробки) застосовуються методи, принципи та правила, визначені цим Законом для отримання натуральної (екологічно чистої) продукції, а також збереження та відновлення природних ресурсів.

Державна політика у сфері виробництва та обігу органічної продукції (сировини) спрямована на створення сприятливих умов для:

- розвитку конкурентоспроможного, високоефективного ведення сільського господарства за допомогою виробництва органічної продукції (сировини);

- збільшення експорту органічної продукції;

- розвитку внутрішнього ринку органічної продукції та задоволення потреб споживачів в асортименті органічної продукції [3].

Органічне виробництво є одним із пріоритетів Міністерства аграрної політики та продовольства України, яка розробила концепцію «3 +5 ». Стратегія передбачає державну підтримку фермерів, реформу держпідприємств, прозорий обіг землі. Реформа проводиться за п'ятьма напрямами:

- розширення ринків збуту;

- органічне виробництво і нішеві культури;

- розвиток сільських територій;

- зрошення;

- безпека харчової продукції [4].

Отже, дослідження стану органічного виробництва та виконання заходів спрямованих на його інтенсифікацію $\epsilon$ актуальним напрямом досліджень, оскільки маючи підтримку на державному рівні, органічні виробники повинні іï відчувати також на місцевих рівнях. Важливо створити умови, які забезпечать розвиток органічного виробництва та стануть поштовхом для розвитку у суспільстві тренду екологічного споживання.

Метою дослідження $є$ оцінка стану та перспектив органічного сільського господарства у регіонах України.

Для досягнення мети поставлені наступні завдання:

- дослідити кількість органічних операторів та операторів перехідного періоду в областях України;

- проаналізувати загальні площі сільськогосподарських земель (з органічним статусом та перехідного періоду, га) в областях України;

- проаналізувати загальні площі сільськогосподарських земель 3 органічним статусом, га в областях України;

- 3'ясувати взаємозалежність між кількістю органічних операторів та площами органічних угідь.

Матеріали і методи досліджень. Дослідження проводилися відповідно до даних Міністерства аграрної політики та продовольства України та міжнародного органу сертифікації «Органік Стандарт». Для дослідження були взяті дані по усім регіонам України, за виключенням теритоpiï АТО (Луганська та Донецька області) та тимчасово-окупованої території АР Крим. Для виконання дослідження було використано метод порівняння. Порівняння - найпоширеніший метод економічного аналізу, який полягає у порівнянні явищ, процесів та показників, що їх характеризують для виявлення спільних рис і відмінностей між ними. Також було застосовано кореляційний аналіз - метод дослідження взаємозалежності ознак у генеральній сукупності, які $€$ випадковими величинами 3 визначення чи це буде проста (парна) кореляція (результативна ознака 3 одним фактором), чи множинна (результативна ознака і декілька факторів) [1].

Результати досліджень. Згідно $з$ даними Мiністерства аграрної політики і продовольства, в Україні налічується понад 420 операторів органічного та перехідного періоду, зокрема 294 сільськогосподарських виробників. Більшість органічних операторів в Україні сертифіковані за органічним стандартом ЄС, що є еквівалентним Регламентам СC 834/2007 та 889/2008, що застосовується як для експорту органічної продукції, так і на внутрішньому ринку. Українські органічні оператори також часто сертифіковані відповідно до Національної органічної програми CША (NOP). Інші органічні стандарти, які використовують в Україні: Bio Suisse (Біо Свісс, Швейцарія), Bioland (Біоланд, Німеччина), Naturland (Натурланд, Німеччина), COR (Канада), Soil Association (Велика Британія) та KRAV (Швеція) [2].

На рисунку 1 наведено дані щодо кількості органічних операторів та операторів перехідного періоду в регіонах України.

Лідерами за кількістю операторів органічного ринку є Київська область (58 операторів), Херсонська, Одеська (по 38 операторів), Житомирська (27 операторів) та Львівська (26 операторів) області. Аутсайдерами органічного ринку за кількістю операторів є Чернівецька (4 оператори), Тернопільська, Сумська (по 7 операторів), Рівненська (8 операторів) та Івано-Франківська (9 операторів) області. 


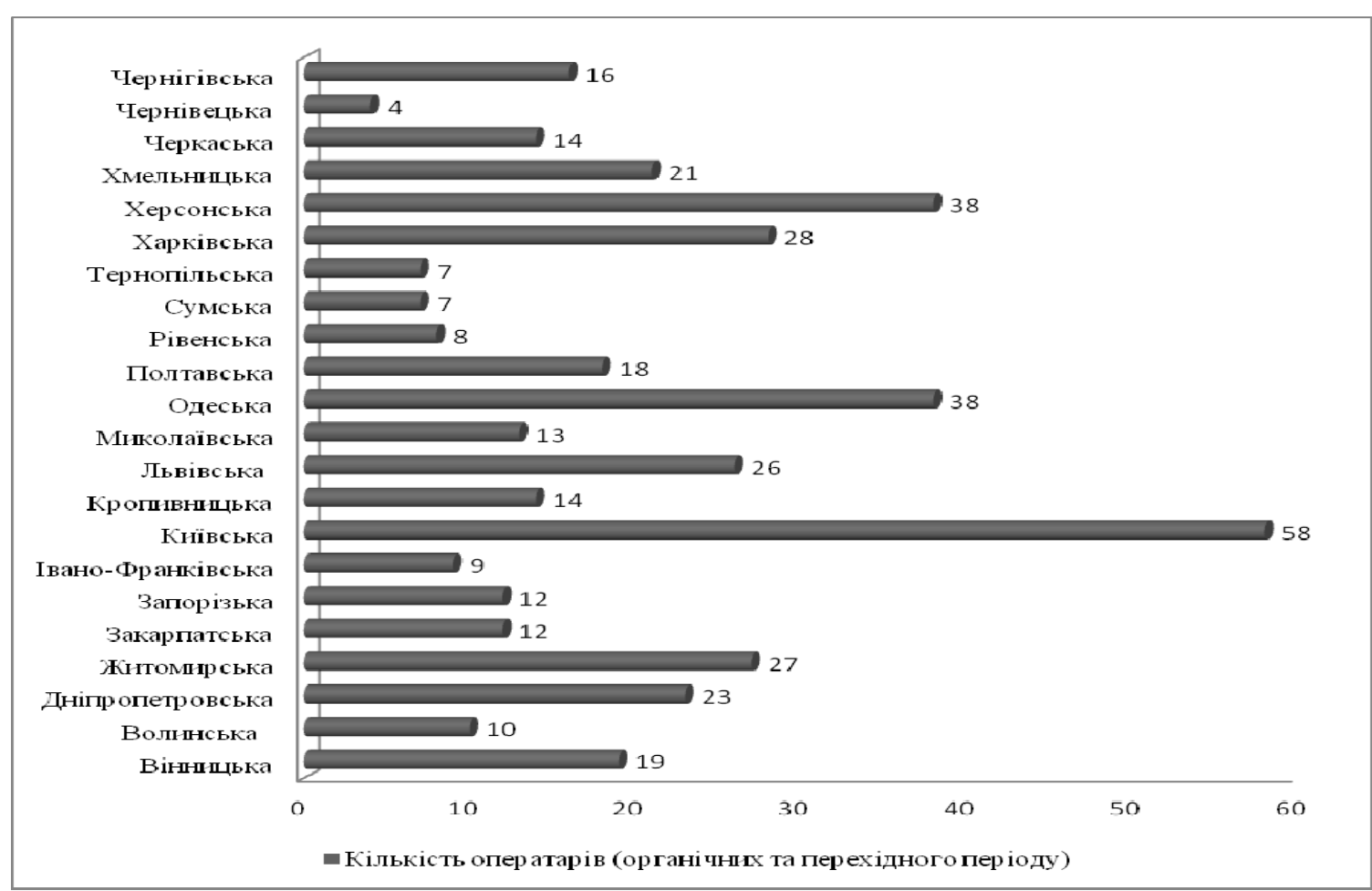

Рис. 1. Аналіз кількості операторів (органічних і перехідного періоду) по областям (за виключенням території АТО та тимчасово окупованої території АР Крим)

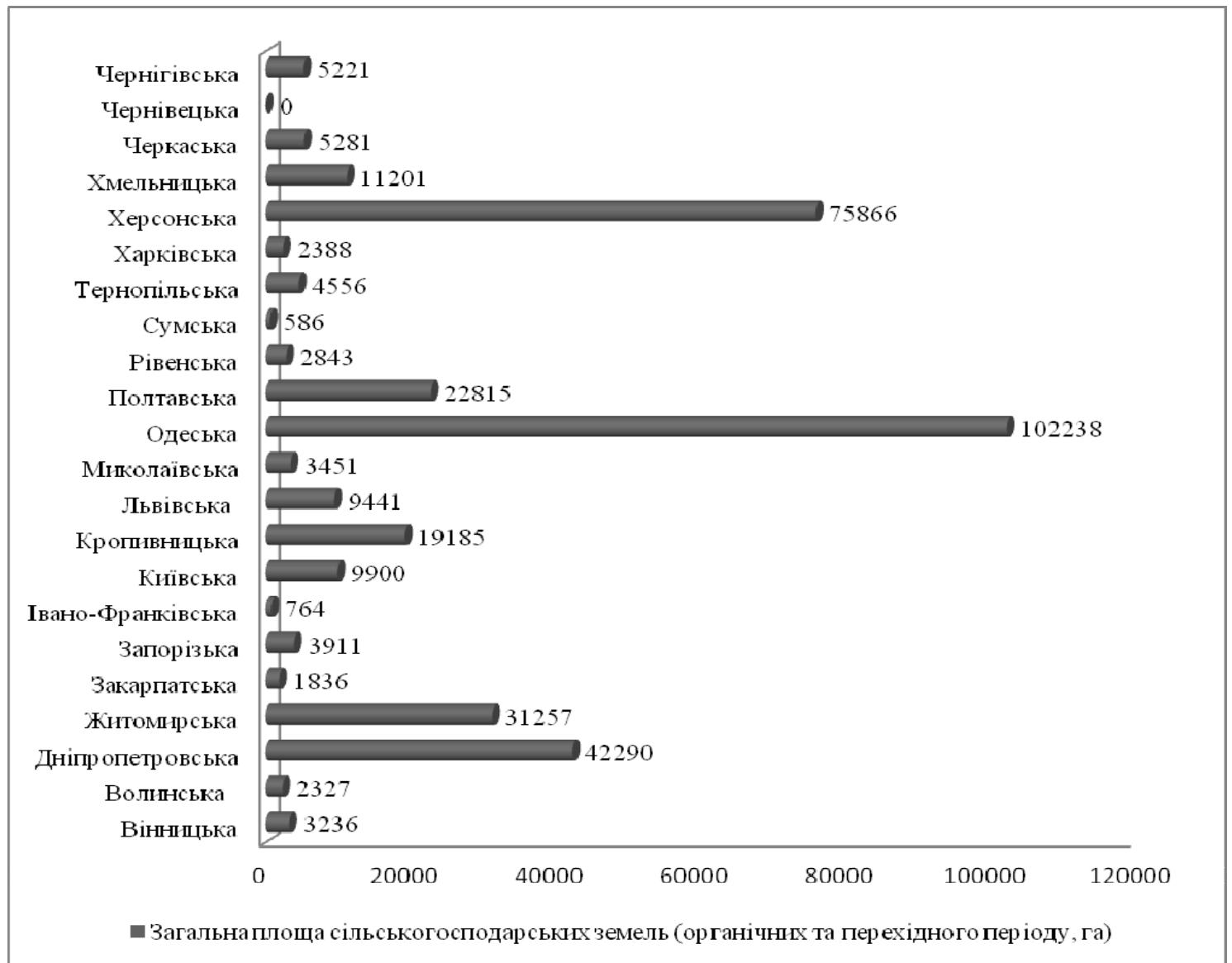

Рис. 2. Аналіз загальних площ сільськогосподарських земель (органічних і перехідного періоду, га) по областям (за виключенням території АТО та тимчасово окупованої території АР Крим) 


\section{СІЛЬСЬКЕ ГОСПОДАРСТВО. РОСЛИННИЦТВО}

На рисунку 2 наведено аналіз регіонів України за загальними площами органічних сільськогосподарських земель та земель перехідного періоду.

Як бачимо 3 рисунку 2, лідерами за площами органічних сільськогосподарських земель і земель перехідного періоду є Одеська, Херсонська, Дніпропетровська, Житомирська та Полтавська області. Найменша кількість площ, зайнятих під органічне виробництво, та площ, що знаходяться у перехідному періоді, зафіксована у Чернівецькій, Сумській, Івано-Франківській, Закарпатській та Волинській областях. Проте слід зауважити, що Закарпатська та Волинські області є порівняно невеликими областями за площею, i, якщо порівнювати кількість органічних земель і земель перехідного періоду з Харківською областю (2388 га), то можна зробити висновок, що Харківська область також знаходиться у списку областей із повільним розвитком органічного землеробства.

На рисунку 3 представлено аналіз регіонів України за загальними площами органічних сільськогосподарських земель.

Відповідно до даних рисунку 3, найбільша кількість органічних земель розташована в Одесь- кій, Херсонській, Дніпропетровській, Житомирській та Кропивницькій областях. Найменшою кількістю органічних земель відрізняються Чернівецька, Сумська, Івано-Франківська, Вінницька та Запорізька області.

Для відображення взаємозв'язку між дослідженими нами були вираховані коефіцієнти парної кореляції між значеннями кількості операторів органічного ринку та загальної площі органічних земель і земель перехідного періоду, а також між значеннями загальної площі органічних земель і земель перехідного періоду та загальної площі органічних земель. Коефіцієнт кореляції відображає ступінь взаємозв'язку між двома показниками та приймає значення від -1 до 1. Якщо коефіцієнт розташувався близько 0, то говорять про відсутність зв'язку між змінними. Якщо значення близьке до одиниці (від 0,9, наприклад), то між об'єктами, що спостерігаються, існує сильний прямий взаємозв'язок. Так, відповідно до отриманих даних коефіцієнт кореляції між значеннями кількості операторів органічного ринку та загальної площі органічних земель і земель перехідного періоду становив 0,55, що свідчить про не досить щільний зв'язок.

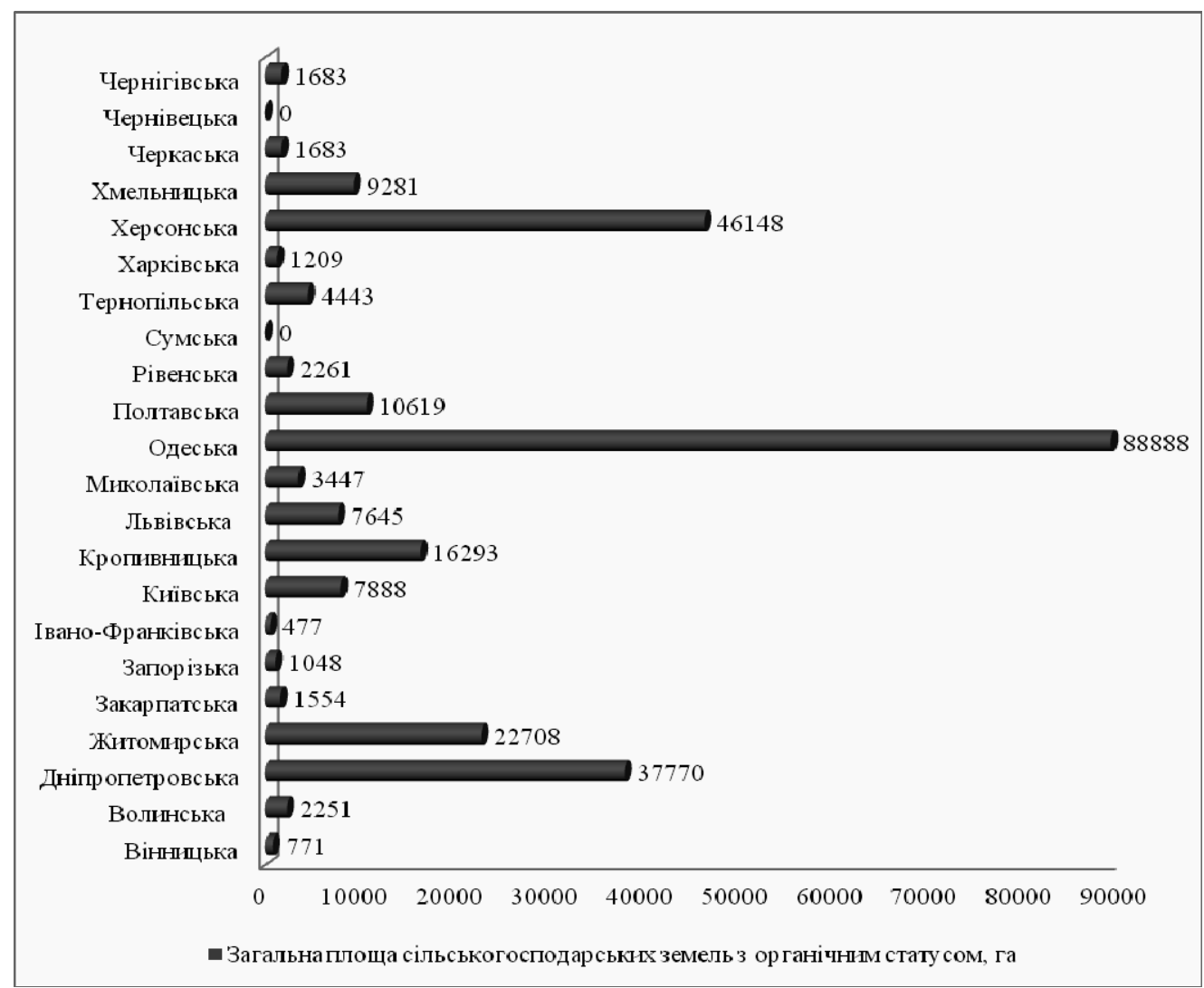

Рис. 3. Аналіз загальних площ сільськогосподарських земель (з органічним статусом, га) по областям (за виключенням території АТО та тимчасово окупованої території АР Крим) 


\section{СІЛЬСЬКЕ ГОСПОДАРСТВО. РОСЛИННИЦТВО}

Це може свідчити про 2 факти: в області функціонують крупні виробники органічної продукції або ж у регіоні зареєстрована значна кількість операторів, що реалізують органічну продукцію, а не виготовляють (як, наприклад, у Київській області). На нашу думку, більшою мірою на кількість органічних операторів, що реалізують органічні продукти, впливає попит споживачів на органічну продукцію в регіоні. Так, наприклад, за кількістю операторів органічного ринку Харківська область $є$ у п’ятірці лідерів, а за кількістю органічних угідь - навпаки. Проте Харків $\epsilon$ великим містом, 3 порівняно високими доходами, що зумовлює значну кількість операторів органічного ринку.

Між значеннями загальної площі органічних земель та земель перехідного періоду і загальної площі органічних земель коефіцієнт кореляції становить 0,98 , що свідчить про тісний взаємозв'язок. Тобто в тих областях, де вже відмічається значна кількість органічних угідь, розвиваються й інші органічні агровиробництва, які зараз знаходяться у перехідному періоді.

Визначені області, де органічне землеробство відсутнє взагалі, - наприклад Чернівецька та Сумська. Проте, якщо у Сумській області відзначається принаймні невелика кількість земель у перехідному періоді, то у Чернівецькій області навіть такі землі відсутні. Варто зазначити, що у Чернівецькій області у 2017 році була затверджена програма економічного і соціального розвитку області, у якій також була приділена увага розвитку органічного сільського господарства. Положення стосовно підтримки органічного землеробства наведені і у Програмі розвитку агропромислового комплексу та сільських територій Сумської області на період до 2020 року.

\section{БІБЛІОГРАФІЯ}

1. Крушельнищька О. В. Методологія та організація наукових досліджень : навчальний посібник. - Київ : Кондор, 2006. - 206 с.

2. Трофімиева О., Прокопчук Н. Органічний ринок в Україні // Офіційний сайт Міністерства аграрної політики та продовольства України. URL : minagro.gov.ua/system/files/Органіка $\% 20$ в\%20Україні\%202018\%20p.docx.

3. Стратегія розвитку аграрного сектору економіки на період до 2020 р. // Федерація органічного руху. URL : http://www.organic.com.ua/ uk/programme-about-organic/strategy.

4. Стратегія «3+5» Міністерства аграрної політики та продовольства України // Офіційний сайт Міністерства аграрної політики та продово-
Тож, пасивність у розвитку органічного землегосподарства полягає не у відсутності державних та регіональних програм підтримки органічного виробництва. Ймовірно, агровиробники не зацікавлені або малознайомі з особливостями органічного виробництва. У такому випадку, важливою $є$ просвітницька діяльність і популяризація здорового та екологічно чистого харчування, а також допомога у пошуках ринку збуту органічної продукції.

Висновки. Тож, найбільша кількість операторів органічного ринку розташована у Київській, Одеській, Херсонській, Житомирській та Львівській областях. Лідерами за площами органічних сільськогосподарських земель і земель перехідного періоду є Одеська, Херсонська, Дніпропетровська, Житомирська та Полтавська області. Найбільша кількість органічних земель розташована в Одеській, Херсонській, Дніпропетровській, Житомирській та Кропивницькій областях. Найменшою кількістю органічних земель відрізняються Чернівецька, Сумська, ІваноФранківська, Вінницька та Запорізька області. Кількість органічних агровиробників у регіоні не впливає на кількість операторів органічного ринку. Також визначено, що наявність державних та регіональних програм підтримки теж не завжди позитивно впливає на розвиток органічного виробництва у регіоні (на прикладі Сумської та Чернівецької областей). Рівень обізнаності, соціальна відповідальність та існування ринків збуту органічної продукції, на нашу думку є більш суттєвими факторами. Проте дані дослідження стали підгрунтям до подальших наукових пошуків у цьому напрямі, зокрема порівняння регіональних програм підтримки аграрних виробників у частині органічного землеробства.

льства України. URL : http://www.organic.com.ua/ uk/programme-about-organic/strategy, http://minagro.gov.ua/system/files/3\%205\%20final. pdf.

5. Хубер Б. Можливості державної підтримки для розвитку сільського господарства. - Київ : ФОП Задорожна С.О., 2013. - 124 с.

6. Council Regulation (EC) No 834/2007 of 28 June 2007 on organic production and labelling of organic products and repealing Regulation (EEC) No 2092/91 // Official Journal of the European Union. URL : http://eur-lex.europa.eu/LexUriServ/ LexUriServ.do?uri=OJ:L:2007:189:0001:0023:EN: PDF. 


\section{ANNOTATION}

Tkachenko A.S. Status and prospects of organic agriculture in the regions of Ukraine.

The article presents data on the state of organic production in the regions of Ukraine. The theoretical aspects of organic production, organic movement and ecological consumption in Ukraine and Europe are researched. The analysis of the number of organic market operators, the total area of land with organic status and land in transition is conducted. Areas with the best trends in organic farming development are identified, as well as the interdependence between the conditions of organic farming and the number of organic operators. For the study data all regions of Ukraine were collected, except for the territory of ATO (Luhansk and Donetsk region) and the temporarily occupied territory of the Autonomous Republic of Crimea.

The largest number of operators in the organic market is located in Kyiv, Odessa, Kherson, Zhytomyr and Lviv regions. The leaders in areas of organic agricultural land and land of transitional period are Odessa, Kherson, Dnipropetrovsk, Zhy- tomyr and Poltava regions. The largest amount of organic land is located in Odessa, Kherson, Dnipropetrovsk, Zhytomyr and Kirovograd regions. The smallest number of organic lands is differed in Chernivtsi, Sumy, Ivano-Frankivsk, Vinnytsia and Zaporizhzhia regions. The number of organic farmers in the region does not affect the number of organic market operators. Areas were identified where organic farming are absent at all - such as Chernivtsi and Sumy. It is established which factors may have an impact on the development of organic production.

It is determined that education and popularization of healthy and ecologically clean food is important, as well as assistance in search of the market for organic products. The recommendations for improving the situation in the field of organic farming are presented and prospects for further research are outlined.

Key words: organic production, organic farming, transitional period, organic market operator, agriculture. 